Hall of Mirrors: Radclyffe Hall's "The Well of Loneliness" and Modernist Fictions of Identity

Author(s): Laura Green

Source: Twentieth Century Literature, Vol. 49, No. 3 (Autumn, 2003), pp. 277-297

Published by: Hofstra University

Stable URL: http://www.jstor.org/stable/3175982

Accessed: 13-05-2016 12:57 UTC

Your use of the JSTOR archive indicates your acceptance of the Terms \& Conditions of Use, available at

http://about.jstor.org/terms

JSTOR is a not-for-profit service that helps scholars, researchers, and students discover, use, and build upon a wide range of content in a trusted digital archive. We use information technology and tools to increase productivity and facilitate new forms of scholarship. For more information about JSTOR, please contact support@jstor.org.

Duke University Press, Hofstra University are collaborating with JSTOR to digitize, preserve and extend access to Twentieth Century Literature 


\title{
Hall of Mirrors:
}

\section{Radclyffe Hall's The Well of Loneliness and Modernist Fictions of Identity}

\author{
Laura Green
}

\begin{abstract}
$\mathrm{I}_{\mathrm{n}}$
1928, as she was preparing to appear as a defense witness in the prosecution of Radclyffe Hall's novel The Well of Loneliness (1928) for obscenity,Virginia Woolf wrote in a letter:
\end{abstract}

At this moment our thoughts center upon Sapphism-we have to uphold the morality of that Well of all that's stagnant and lukewarm and neither one thing or the other; The Well of Loneliness. (Woolf 555; also qtd. in Cline 255) ${ }^{1}$

Woolf's response to The Well-privately caustic, publicly supportive-prefigures the ambivalence that the novel has famously continued to arouse among readers and critics. The Well appeared on the heels of the critical and popular acclaim accorded Hall's novel Adam's Breed (1926), recipient of the 1927 Prix Femina Vie Heureuse (which Woolf herself won the next year), and Hall's novels share certain concerns with Woolf's. Like Woolf, Hall created female protagonists who are artists (A Saturday Life) or writers (The Well of Loneliness), whose thwarted ambitions include an Oxbridge education (The Unlit Lamp), who may challenge conventional gender expectations (The Unlit Lamp, The Well of Loneliness), and whose lives are shaped by powerful (although in Hall's case almost entirely negative) mother figures who embody traditional feminine morality (The Unlit Lamp, The Well of Loneliness.) But Hall is not among the contemporary authors discussed in Woolf's literary journalism.

Woolf's dismissal of Hall has traditionally been read as a marking of 
the boundary between modernist aesthetics and the traditions of Victorian and Edwardian realism from which modernism distinguished itself. As Joanne Winning writes, Woolf "attempts to draw a line between [The Well of Loneliness] and other, more innovative literature being produced around it" (372)—including, presumably, Woolf's own covertly "Sapphic" Orlando, published shortly after The Well of Loneliness. ${ }^{2}$ But the terms of Woolf's critique beg more questions about boundaries than they resolve: With respect to what counter-possibilities of motion and heat is the novel "stagnant and lukewarm"? What are the poles between which it falls, the "one thing" or "another" that it fails to be? According to what criteria, in other words, does Hall's novel exhibit the in-betweenness that seems to be the source of Woolf's unease? If it is in-betweenness that is at the root of negative responses to the novel, might it be possible to read that in-betweenness differently, as a source of the novel's strength rather than its weakness? Finally, might Hall's depiction of an "inbetween" identity illuminate the problems of grounding narratives of identity in modernist narrative and beyond?

Certainly, Hall's curiously "lukewarm" stance toward her immediate literary context - the aesthetic context of high modernism and the intellectual context of Freudian theorizing-seems suggestivh278as a ground for Woolf's reaction. "Neither one thing nor another" accurately describes The Well's relationships to, on the one hand, a Victorian narrative concern with the social and material milieus and, on the other hand, a modernist concern with interior consciousness. The Well's opening sentence- "Not very far from Upton-on-Severn-between it, in fact, and the Malvern Hills — stands the country seat of the Gordons of Bramley; well-timbered, well-cottaged, well-fenced and well-watered" (11) - could not more firmly announce its nostalgia for agrarian, country-house society and, by extension, the traditional novel to which such a setting appertains. And yet Stephen Gordon's trajectory propels her firmly out of the milieu thus announced, into a future defined by exile. The "country seat" becomes a painful reminder, embodying "that inherent respect of [sic] the normal which nothing had ever been able to destroy [in Stephen] ... an added burden it was, handed down by the silent but watchful founders of Morton [Hall]" (430). Similarly, if the novel's plotting notably depends upon the conventions of the heterosexual romance, its climax, in which Stephen engineers her own romantic rejection and embraces authorship as a lonely, terrifying, but generative form of possession, makes clear Hall's 
belief that she and her heroine were plotting an alternative, if not entirely new, fictional trajectory. Hall's relationship to both the topographical and the relational landscapes of the traditional novel, while often nostalgic, also conveys a clear sense of their current insufficiency and the necessity for their passing.

Like her relationship to the traditional novel, Hall's orientation toward the psychological discourses available to her may be less reactionary than has sometimes been suggested. It is true that, at a moment when the Woolfs' Hogarth Press was disseminating Freudian accounts of sexuality and identity, which tend to represent sexual dispositions as psychological in origin and sexual behaviors as acquired, Hall turned firmly back toward the sexological tradition (whose primary English exponent, Havelock Ellis, contributed a prefatory note to The Well), which represents sexual disposition as congenital, if not hereditary, and an effect of physical rather than mental organization. ${ }^{4}$ And yet, as Jeanette Foster noted nearly half a century ago,

There is a blur in the explanation of Stephen's variance. Emphasis on her physical masculinity indicates hereditary causes, as does her father's early recognition of her anomaly. But his consequent indulgence of her proclivities, and the stress laid on both parents' desire for a male child, hint at belief in prenatal as well as childhood conditioning. $\quad(281)^{5}$

Hall was hardly alone in this "blurring": as George Chauncey points out in his discussion of the transition from a model of "sexual inversion" to one of "homosexuality" during the first several decades of the twentieth century, "Freud's American followers and other non-Freudian psychiatrists continued to mix his radically mental explanation of homosexuality with those which attributed the 'disorder' to congenital defects and even to vice" (137). According to Elizabeth Abel, Woolf herself "claims to have avoided reading Freud until 1939, a deferral that must have required some effort, since from 1924 . . . the Woolfs' own Hogarth Press published the English translation of every text Freud wrote" (14). The confused origin story that Hall gives Stephen is to some degree emblematic of a more general confusion, during the period, of how to conceptualize and represent identities.

Finally, the novel's - and its protagonist's - quality of being "neither one thing nor the other" draws attention to the difficulty for realist nar- 
rative, across historical moments, of representing identities. How do fictions of individual development create, represent, and narrate identities to and for their readers? What is the relationship of lived identities to fictional ones, and of fictional identities to the traditions from which they emerge? Hall's negotiation of a variety of narrative and psychological schemata available to her as an heir to Victorian and Edwardian discourse is most visible in her literary construction of Stephen Gordon's identity from intertextual materials - sexological, Biblical, literary, and epistolary texts. What is, I shall argue, a radically intertextual constitution of Stephen's identity has several effects. On the one hand, the very lack of seamlessness in this constitution-Hall's vacillations among models for, and rhetorical representations of, the identity of the "invert"- has perhaps helped to make Stephen available as an object for identification to successive, and differently situated, generations of readers and critics, who may identify with those representations selectively. On the other hand, the novel's quite visible struggle to create an identity for its protagonist, and the indeterminacy arising from the heterogeneity of the materials brought to bear, raise the question of whether identities can be represented as anything but constructed and indeterminate.

The Well of Loneliness exemplifies a model of identity common to novels of development both Victorian and modern-a model in which identities are not merely described by, but actually rooted in, literary narrative, through the protagonists' intertextual identifications. As described by Jacques Lacan's revision of Freudian theory, identity is formed through a series of aspirational and ultimately unachievable identifications: what we call "identity," then, is always a fantasy of identity, a projection of self. ${ }^{6}$ Novels of development capture this phantasmatic aspect of identity by grounding their protagonists' identities in a mise en abyme, or infinite regress, of fictional identifications. Characters' attempts to experience themselves as "real" lead them inexorably further into a loop of narrative; that is, every description or inscription of identity turns out to depend upon an identification with some other description or inscription. The Well of Loneliness, which ends with its protagonist giving metaphorical birth to a novel that is essentially the one whose plot she has just traversed, exemplifies this tendency.

This availability to, and exemplification of, processes of readerly identification might account for the currency maintained by The Well of Loneliness despite the novel's notoriously mixed reception among readers and 
critics. For one anonymous reader, The Well is a drowning pool: "When I was nineteen I wasn't able to finish it, I think the prose style and class assumptions put me off. Had I finished reading the novel then I think it would have been very harmful" (qtd. in O'Rourke 122). For another reader, however, it serves as a wellspring: "I saw myself reflected on those pages where Stephen Gordon lived," writes the novelist Donna Allegra: "I, a black girl, Brooklyn-born and raised, had something important in common with this upper-class British noblewoman, something beyond a love for fencing and riding horses" (71).

Stephen's identity has provoked similarly varied reactions among academic readers. Over some 80 years Stephen has been read successively as an exemplar of a new social category, "inversion"; a tragic remnant of patriarchal gender definition; a defiant fifties butch; and an avatar of "what we now call a transsexual identity" (Halberstam 85). Most recently, Halberstam and Jay Prosser have argued persuasively for readings of Stephen Gordon's "inversion" as an example not of lesbianism but of "female masculinity" (Halberstam) or transgender identity (Prosser, particularly 155-68). In fact, the gender and sexuality of Hall's protagonist have been critically unstable, shifting as her in-between narrative is refracted through new interpretive lenses. ${ }^{7}$

Stephen has also been hailed as an available object of identification even by those readers who do not inhabit the categories of sexual identity into which she has been assimilated. "Even though I am 'Feminine' in appearance," remarks one reader, "I identified with Stephen and admire her. The ending of the novel dismayed me so that I rewrote it" (qtd. in O'Rourke 119). This anonymous respondent's appropriation of authorial control suggests that Stephen's is what we might call, adapting Roland Barthes's term, a "readerly" identity —an identity whose ontology is coextensive with its representation and one that is, therefore, available to successive interpretations. In what follows, then, I argue that a reading of Stephen Gordon's sexual identity as one that signifies primarily through its discursive transformations is supported by the novel itself. Hall's construction of her protagonist undercuts its own notorious and apparently binding reliance on positivistic and biologistic accounts of identity by constructing Stephen's identity as a textual mise-en-abyme. The purpose of such a reading is not to deny that, as one of her biographers asserts, Hall was "resolutely middle-brow" as both a reader and a writer (Baker 145), but rather to suggest that discursive and ideological 
complexity of various kinds is not confined to high-culture literary objects but can be found in that literary middle that is, once again, "neither one thing nor another."

$\mathcal{S}$

Hall narrates Stephen's development as a succession of relationships to different genres of narrative and representation. First, Stephen's identity appears to be both entirely unnarratable and outside of genre. Second, she enters into available narrative systems - on the one hand, the public, masculine, and "expert" narratives of sexology and theology, and, on the other hand, the domestic, feminine, and informal narratives of slander and gossip - to find that they make her legible only as marked and abject. Finally, she attempts to assert herself as the author of a new and transformative narrative, a work of fiction that resembles The Well of Loneliness itself.

Stephen's expression of gender, which she and others experience as masculine, and her sexual desire, which is directed toward women, initially render her illegible within her social milieu (which is that of the Edwardian country gentry). Stephen is biologically female, and the expectation is that her expression of gender will reflect biological femininity, while her sexual desire will seek a masculine object. Her contrary appearance and predilections appear to be outside the available sex/gender narrative and therefore appear simply not to be. As an adolescent, Stephen reflects, "I'm nothing-yes I am, I'm Stephen-but that's being nothing" (70). The words that her neighbors use to describe her as she grows into adolescence-“"queer," "freak," "unnatural"-merely emphasize her inaccessibility to discourse, rather than interpellating her within it:

Could Mrs. Antrim have ignored Stephen Gordon's existence, she would almost certainly have done so.... What she called Stephen's "queerness" aroused her suspicion-she was never quite clear as to what she suspected, but felt sure that it must be something outlandish.

Stephen's mother, Lady Anna, on discovering Stephen's first (unconsummated) affair with a woman, Angela Crossby, declares: "This thing that you are is a sin against creation" (200). Like all of Stephen's antagonists, she can name her only tautologically as "this thing that you are"-a cir- 
cularity of reference that brings Stephen no further into narrative. Later, Angela herself demands: "CCan I help it if you're-what you obviously are?" (149). But what is "obvious" to Angela (a former chorus girl) remains baffling to Stephen. To be neither one thing nor the other in gender terms is to be both obviously wrong and utterly invisible.

As Stephen grows older she internalizes this illegibility, trying and failing to produce an ontological counternarrative:

But what was she? Her thoughts, slipping back to her childhood, would find many things in her past that perplexed her. She had never been quite like the other children, she had always been lonely and discontented, she had always been trying to be someone else. (100)

Only Stephen's father, the scholarly Sir Philip, might be able to supply the answers Stephen seeks. Early on, we see him (though Stephen does not) in his study reading a sexological text: "A slim volume recently acquired.... The author was a German, Karl Heinrich Ulrichs, and reading, Sir Philip's eyes would grow puzzled; then groping for a pencil he would make little notes all along the immaculate margins" (26). But although Stephen will later read her identity there, in the margins of her father's books, Sir Philip, "a coward because of his pity" (106) chooses to keep his knowledge from her. When he is killed in an accident, his deathbed attempt to enlighten his wife serves only to prolong Stephen's state of nonexistence: "Anna-it's Stephen-listen. . . It's-Stephen-our child—she's, she's—it's Stephen—not like—" (118). Stephen remains, in Sir Philip's last words, negatively defined: not "like," but unlike, an "it" whose lack of identity is indicated by the presence of a copula without the predicate it demands.

It is after her father's death, when she must leave Morton, that Stephen begins to move from being entirely outside of narratives of identity to taking on, with both reluctance and relief, a conscripted and marginal, but at least legible, identity as an "invert." This identity almost foists itself upon her. As she enters her father's library, she is seized, helplessly, by narrative:

As she slipped the key into the lock [of the bookcase], the action seemed curiously automatic.... Then she noticed that on a shelf near the bottom was a row of books standing behind the others; 
the next moment she had one of these in her hand, and was looking at the name of the author: Krafft-Ebing - she had never heard of that author before. All the same she opened the battered old book, then she looked more closely, for there on its margins were notes in her father's small, scholarly hand and she saw that her own name appeared in those notes. (204)

This is the third of three times that Hall introduces the name of a sexologist into the narrative (the first is Havelock Ellis's signature in the novel's prefatory "Commentary," the second Sir Philip's reading of Ulrichs). On this, as on the prior occasions, she withholds the title of the text and any description of it. Invoking sexology only synecdochically, by the proper names associated with it, Hall avoids tainting her characters with the other "perversions" discussed - by Krafft-Ebing, for example-or allowing their medical authority to overshadow the authority she is claiming for literary representation. At the same time, readers who do not accept the authority of the fictional text are referred to assertively empirical ones. The revelation of Stephen's identity is a narrative revelation, but its authority hovers uneasily between two narrative forms: the scientific, which represents the phenomenologically "real"; and the fictional, which represents the emotionally "true."

Stephen's own reading of these texts, however, at first seems not to liberate her into ontology or phenomenology, but rather to bury her further and further within text, with ambiguous results. Certainly, the expert volumes-medical and theological-in which she discovers her identity at first appear to impose themselves upon her with a scientistic authority in the forms of taxonomy and case history. But this authority is mixed in its effects. On the one hand, the Psychopathia Sexualis is a taxonomy of "deviant" sexual practices, a compilation of hundreds of cases of tabooed behavior including fetishism of various kinds, sadism and masochism, coprophilia and necrophilia, as well as a range of forms of "inversion," or homosexuality. Individual cases are numbered and related pseudonymously. As Krafft-Ebing derives these cases from his experience as both a practicing physician and psychologist and an expert medical witness, their context is pathological or criminal, and Krafft-Ebing himself generally equates the behavior he describes with physical and social deviance. His project in this sense seems to contribute to the nine- 
teenth-century development of "technologies" of sexuality and the pathologization of sexual behavior that, as many critics have argued, contributed to the criminalization and persecution of homosexuality. ${ }^{8}$

On the other hand, the sheer variety of Krafft-Ebing's project and the narrative detail of some of his examples work against this taxonomic and proscriptive organization. In his introduction, Krafft-Ebing claims that his subjects are deviant because they controvert "the hidden laws of nature which are enforced by a mighty, irresistible impulse" (23). But his own taxonomic enterprise itself undermines the assertion that these "laws" are irresistible. First, there is the sheer number and detail of his casessome five hundred overt challenges to "the hidden laws of nature." Second, the narrative form that he more or less fully adopts- the case history-undermines the purely classificatory impulse of taxonomy. Thomas Laqueur claims that the case study arises in the eighteenth century as one of a number of discourses that form what he calls "the humanitarian narrative." The aim of "humanitarian narrative" is to shape the "unprecedented quantities of fact, of minute observations, about people who had before been beneath notice" (177) into links of cause and effect that would provoke readers to compassion with, and action on behalf of, suffering others. This aim also belongs, as Laqueur notes, to the emerging form of the novel. ${ }^{9}$ Such narratives put into play readerly impulses of sympathy and even identification that can counter the estranging direction of categorization.

One of the cases in the Psychopathia Sexualis that most reveals the features of such a "humanitarian narrative" is also the example of female homosexuality that most closely resembles Stephen's situation, in the protagonist's aristocratic station, her masculine identification, and her desire for women - the narrative of the pseudonymous Sandor. ${ }^{10} \mathrm{Krafft}-E b i n g$ cites Sandor as an exemplification of "Gynandry"- "the extreme grade of degenerative homosexuality" (335). A wealthy, masculine, cross-dressing "authoress," Sandor enters into a fraudulent marriage with an apparently heterosexual woman, which she maintains for a year before being discovered. Krafft-Ebing devotes to Sandor an unusually extended and sympathetic treatment. ${ }^{11} \mathrm{~A}$ tragic romance in miniature, Sandor's story compels Krafft-Ebing's admiration, and through him the reader's as well. He emphasizes her identity as an author and transcribes her words: 
[Sandor's] writings betray a wonderfully wide range of reading in classics of all languages, in citations from poets and prose writers of all lands.... This writing ends with the apostrophe:"Gentlemen, you learned in the law, psychologists and pathologists, do me justice! Love led me to take the step I took; all my deeds were conditioned by it. God put it in my heart. ... Only God is just. How beautifully does Victor Hugo describe this in his Légendes du Siècle! How sad do Mendelssohn's words sound to me: 'Nightly in dreams I see thee'!" (360-61)

The voice of Sandor, as Krafft-Ebing transcribes it, brings into the text a note of literary, rather than medical, authority. Sandor's words challenge the codifications of the taxonomy in which they are embedded by celebrating the emotional plenitude of Romantic representation.

But what Krafft-Ebing makes audible here is not a "true" voice of "inverted" identity, piercing through an obscuring medium of text. As Prosser points out, Krafft-Ebing's analysis of Sandor is taken from her written autobiography, leaving Krafft-Ebing in the role of "an unintended (or at least unspecified) reader" (Prosser 146). The scene of Stephen's reading is a scene of the reading of reading: her reading of her father's reading of Krafft-Ebing's reading of the words of Sandor, who reads Hugo and Mendelssohn. This recursive textual identification emphasizes the extent to which "identity" is not an emergence from representation into the "real," but a multiplication of longing for its impossible attainment—an impossibility underlined in the cross-dressing Sandor's (and the cross-dressing Stephen's) longing for a masculinity unavailable by definition. Stephen remains here "in between." She is in between the empirical authority of taxonomic discourse and the emotional authority of fictional representation.

At the same time, it is important that the abyss pauses, if it does not end, with Hugo and Mendelssohn - that is, with the literary voice; for that is where authority, both Hall's and Stephen's, will come to rest at the end of the novel. Now, however, Stephen turns from medicolegal to theological text. Like the Krafft-Ebing volume, the Bible seems to seek Stephen out, rather than vice versa:

Before she knew what she was doing, she had found her father's old, well-worn Bible. There she stood demanding a sign from 
heaven.... The Bible fell open near the beginning. She read "And the Lord set a mark upon Cain." (204)

Like the Psychopathia, the Bible marks and classifies Stephen, not with scientific enumeration but by heavenly branding. But once again, the moment of dispossession is also a moment of genesis, not only a rebirth but a double birth for Stephen, who can now predicate her own identity upon a textual identification ("I am like Sandor" or "I am like Cain"). The scene does not end with the Biblical curse. Stephen's companion, Miss Puddleton-whose nickname, Puddle, suggests a pliant morphology that counters patriarchal rigidity - briskly announces Stephen's vocation as a writer: "Just because you are what you are, you may actually find that you've got an advantage. You may write with a curious double insight-write both men and women from a personal knowledge" (205). Puddle's circumlocution once again states Stephen's identity only as the unspeakable. But "you are what you are" (with its echo of Jehovah's "I am that I am") casts its tautology not as lack or in-betweenness but as a doubling - a super-sufficiency that, like Stephen herself, will transcend the binary of gender. "Where you go, I go, Stephen," Puddle further declares (205). With this echo of Ruth's words to Naomi, she demonstrates the power of revision, countering a Biblical story of fratricide and patriarchal punishment with an equally canonical but redemptive story of female solidarity that turns exile into quest.

The project that Puddle enjoins upon Stephen-in effect, to give literary birth to herself-is, however, difficult, and not only because, as many critics have pointed out, Hall herself is unwilling completely to abandon classificatory and stigmatizing narratives. She also resists a counteridentification of redemptive narrative with feminine narrative practices, as against the undeniably patriarchal voice of the medical and Biblical texts. Stephen must also experience the stigmatizing effects of feminine, informal, and ostensibly domestic forms of narrative.

The most traditionally feminine narrative mode, in English literary culture, is the epistolary, a mode on which The Well of Loneliness draws. Letters in the novel are generally written by women; men who write letters, including Angela Crossby's husband Ralph and Stephen's "invert" acquaintance Jonathan Brockett, are represented as effeminate. Even when letters are well-meaning and sincere, their circulation is damaging to Stephen. For example, when she writes to Angela Crossby an agonized 
outpouring of her unconsummated love and selfless devotion, it brings about her banishment from Morton. Stephen has not considered the letter's potential for uncontrolled circulation and for being misread; it reaches Angela's husband Ralph, who "read [the letter] slowly, and as he did so his weak little eyes grew literally scarlet-puffy and scarlet all over their lids" (198). Reading Krafft-Ebing opened Stephen's eyes; reading her letter narrows Ralph's already weakened vision. He forwards a copy to Stephen's mother, Anna, causing the final estrangement between mother and daughter.

At their worst, then, letters not only deny but insidiously pervert narrative as a source of identity. They appear to speak the self, but their real effect is to police social boundaries through the circulation of slander, innuendo, and shame, often through recourse to the representation of Stephen's identity as not really representable: "With deep repugnance," Ralph writes, "I take up my pen, for certain things won't bear thinking about, much less being written.... I enclose a copy of your daughter's letter to my wife, which I feel is sufficiently clear to make it unnecessary for me to write further. ..." (199). In its malicious use of paralepsis, Ralph's letter compares unfavorably both with the Psychopathia-which at least offers Stephen a name and a narrative-and with Stephen's own effusion to Angela.

As Ralph's letter separates Stephen from Morton and from her first love, a similar letter, from a woman, later brings about the beginning of the end of Stephen's first consummated romance, with Mary Llewellyn, a young, working-class Welsh woman with whom she settles in Paris after World War I. After Stephen becomes a successful novelist, she and Mary form a friendship with an elderly peeress, Lady Massey. But then a letter comes,

a long, rambling, pitifully tactless letter, full of awkward and deeply wounding excuses...."The rumours that have reached me about you and Mary-certain things that I don't want to enter into-have simply forced me to break off our friendship." (370)

Like Ralph's, this letter does its damage by speaking of Stephen and Mary only as the unspeakable.

Letters that circulate, alternately, silence (the erasure of identity) and scandal (false and conscripted identity) come to be the force of a largely 
feminine-administered rule of social convention that proves more immediately destructive than authoritative discourses such as sexology or theology. This force finally persuades Stephen to sever the relationship and drive Mary into the arms of Martin, an old friend of Stephen's. This painful conclusion has aroused protest in readers, who have found it implausibly motivated and unnecessarily tragic in its implication that Stephen's only honorable course is one of loneliness and celibacy. Critics, too, take Hall's apparent capitulation to the logic of the heterosexual romance plot as evidence of the difficulty of reforming that plot from within its own assumptions.

To some degree, such responses perhaps confuse readerly desire with narrative logic. Yet it is the didacticism and polemical thrust of the novel itself that partly arouse that desire. The longing for a fictional representation to solve, or at least respond to, problems apparently outside of that representation-that is, experienced within history and social life-is voiced within the novel itself, most notably in a speech made to Stephen by a character who is urging her to take up "inversion" as a topic for fiction: ordinary people "will not read medical books; what do such people care for doctors? ... The doctors cannot make the ignorant think, cannot hope to bring home the sufferings of millions; only one of ourselves can some day do that" (390). Though Stephen responds to this exhortation with skeptical silence, she embraces this duty at the end of the novel. Agonized by Mary's departure, she becomes "possessed" by the voices of her fellow inverts: "And now there was only one voice, one demand; her own voice into which those millions had entered" (437). Narrating and narrated subject fuse as Stephen conceives a novel that is, clearly, the novel of which she herself is the protagonist. Hall unites the narrated and the narrator to suggest that the former can become the latter-that the narrated subject can seize control of narrative.

But there is no question that Stephen's assumption of narrative, rendered as possession, is as much a painful and overwhelming loss of control as a seizing of discourse: "In their madness to become articulate through her, they were tearing her to pieces, getting her under. They were everywhere now, cutting off her retreat; neither bolts nor bars would avail to save her. The walls fell down and crumbled before them" (437). Similarly, The Well of Loneliness remains "possessed" by fragments of the conscripting narrative conventions that ground Stephen's own identity. These fragments include first of all the sexological "expert" discourse 
that Hall relies upon even as she attempts to revise and reappropriate it. Hall persuaded the sexologist Havelock Ellis to contribute a commentary as a preface to The Well of Loneliness, which asserts that "apart from its fine qualities as a novel ... it possesses a notable psychological and sociological significance" (n.pag.). Hall herself cannot resist sexological taxonomy in introducing the panoply of "inverts" whom Stephen meets in Paris: "The grades were so numerous and so fine that they often defied the most careful observation. The timbre of a voice, the build of an ankle, the texture of a hand, a movement, a gesture" (352). Appeals to theological as well as medical authority retain a primary place in the novel, which ends with Stephen's prayer: "Acknowledge us, oh God, before the whole world. Give us also the right to our existence!" (437).

At the level of narration, one stylistic trait of Hall's particularly reveals the traces of narrative determination that her emphasis on Stephen's assumption of narrative agency denies. This trait is her use of "must" as an auxiliary verb to depict actions and states that rarely seem to require the attribution of compulsion-particularly, but not only, moments of emotional connection:"After a while [Sir Philip] and Anna must get talking, amusing themselves irrespective of Stephen" (36); "For hours [Stephen] must play stupid doll-games with Violet" (47); "Because [Sir Philip] loved [Stephen] he must equally suffer" (108); Puddle, watching Stephen pursue Angela Crossby, "must be tormented by memories dug out of their graves by Stephen" (156). When Stephen returns from the French front and greets the servants: "Adèle must start to gabble about Jean ... and Pauline must interrupt to tell of the neighbouring baker who had lost his four sons.... And presently she must also deplore the long straight scar upon Stephen's cheek.... But Pierre must point to the green and red ribbon in Stephen's lapel" (296).

The construction of obligation grows particularly pronounced as Stephen and Mary begin to acknowledge their love: "After a while [Mary's] eyes must turn, as they always did now, to rest upon Stephen; while Stephen's uncertain and melancholy eyes must look back with great love in their depths for Mary" (306). The insistence on compulsion gives to affect and desire in the novel a Racinian fatality: Hall's characters do not simply experience emotion; they are overborne by it. This emphasis on the ineluctability of desire is presumably intended to relieve the characters of responsibility for acceding to it- "God put it in my heart," as Sandor alleges-but it implies a compulsory architecture of tragic con- 
vention at odds with Hall's equally implicit assertion of narrative agency. In its conclusion, the novel remains in an in-between state, torn between the empiricism of taxonomy and the exemplification of fiction, between compulsion and election.

The Well of Loneliness and its heroine can seem haunted not only by stigmatizing discourses but also by fictional convention. Julie Abraham has argued that novels conventionally referred to as "lesbian novels," such as The Well of Loneliness, "are formula fictions based on the heterosexual plot" (xix). "There is," she asserts,

no corresponding "lesbian plot." There could be no "lesbian plot" equivalent to the heterosexual plot, because the construction of heterosexuality is in modern culture the construction of heterosexuality as the norm, and because the function of literary conventions, like all conventions, is to normalize. $\quad(3)^{12}$

Certainly, The Well of Loneliness struggles with both internal and external impulses toward normalization, and Mary's departure with Martin reflects this. At the same time, however, I want to argue that this outcome need not be read as a complete triumph of previous fictional convention. Acknowledging that "the heterosexual plot and its ideological effects could be challenged from within the formula of the lesbian novel," Abraham writes of The Well of Loneliness that it "concludes with a wedding, but it is the marriage of Stephen's lover Mary, which disrupts the novel's central relationship but leaves one lesbian committed to her deviance" (13).

This concession, however, understates the "challenge" posed by the novel. In fact, it does not "conclude with a wedding": when Mary leaves with Martin (with Stephen in something like the role of the angel with the fiery sword), she exits from the novel as well as from Stephen's life. We may assume a wedding, but we never witness one. Unlike previous stories of heroines who express artistic ambitions or rebel against the conventions of heterosexuality-for example, Madame de Staël's Corinne (1807), George Eliot's The Mill on the Floss (1859-60), Kate Chopin's The Awakening (1899), and Virginia Woolf's The Voyage Out (1915)—The Well of Loneliness does not demand either its protagonist's marriage or, as the price of avoiding it, her death.

Perhaps, then, it is not necessary to view Mary's expulsion from Stephen's life as evidence of a tragic vision. By the time Mary leaves, 
Stephen has already become a successful author, and Hall makes it clear that the younger woman's needs for attention and protection would have hampered Stephen in the important work of creating that new narrative through which Stephen, and others like her, will become legible. Fiction, Hall suggests, can steer a course between the esoteric and pathologizing vocabularies of patriarchal medical and theological texts on the one hand, and the all-too-well-circulated malice of feminine gossip on the other. Like many male protagonists of the genre-James Joyce's Stephen Dedalus, D. H. Lawrence's Paul Morel-Stephen finds her triumph in turning away from, not taking her place within, the domestic plot. She steps from the conclusion of the romance into the conclusion of the kunstlerroman, or novel of artistic development.

In its invocation of a future of narrative to which Stephen belongs, Hall's conclusion also anticipates Woolf's conclusion to A Room of One's Own (1929):

The opportunity will come [for the woman writer] and the dead poet who was Shakespeare's sister will put on the body which she has so often laid down. Drawing her life from the lives of the unknown who were her forerunners, as her brothers did before her, she will be born.

The new woman writer of Woolf's utopia remains a fictional conception, "drawing her life" from a phantasmatic literary source. Regardless of the significant differences in the aesthetic and political investments of their authors, these conclusions share an orientation toward a narrative future that both emerges from, and transforms, the narrative past-but that never escapes it. Despite or even because of its vacillating representative strategies and frequently abjected status within modernism and within gay/lesbian and queer studies, The Well of Loneliness offers a reminder that identities, whether of literary movements, of genres, or of persons, are narrative effects that are continually subject to rereading and rewriting.

\section{Notes}

1. In another letter she writes that "The dulness of the book is such that any indecency may lurk there-one simply can't keep one's eyes on the page" (Letters 556); in her diary at the same time she calls the novel "the pale tepid 
vapid book which lay damp and slab all about the [magistrate's] court" (Diary 207). For similar dismissals see Diary 3:193n6 and Letters 3:520. In the trial, the magistrate disallowed evidence about the literary merits of the novel, and Woolf was not called upon to testify. For an account of the trial, see Brittain; the events are also summarized in Baker 223-47 and Cline chap. 16.

2. On the "materialism" and irrelevance of Edwardian/Georgian writers cf. Woolf, "Modern Fiction." For comparisons of the aesthetic and thematic approaches of The Well of Loneliness and Orlando, see Winning 375-83 and Parkes. Also relevant to any comparison of Hall and Woolf is the strong argument made by Marcus for Woolf's intertextual awareness of, inspiration by, and allusive inclusion of The Well in A Room of One's Own (1929).

3. Winning makes the case for The Well of Loneliness as a constitutively modernist novel, and lesbianism as a constitutively modernist identity, based on parallels among Hall's novel,Virginia Woolf's Orlando, and Dorothy Richardson's Pilgrimage. I am interested less in identifying canonically "modernist" moments in or aspects of Hall's novel than in suggesting the continuity, and controversy, of textual constructions of identity across generic/literary-historical boundaries. For another discussion of generic modernism in The Well of Loneliness, see MacPike.

4. See Abel 14. Hall does not appear to have read Freud, although Baker notes that Freud's Leonardo da Vinci: A Psychosexual Study appears in a 1921 list of books to be read in the diary of Una Troubridge, Hall's companion (Baker 218, 145).

5. Cf. Chauncey for a succinct formulation of the distinction between sexological and Freudian theories about the basis of homosexuality:

One of Havelock Ellis's major purposes was to establish the congenital basis of homosexuality; he considered this theory to be politically progressive, since it might remove homosexual behavior from the purview of the law.... Ellis and other sexologists also postulated the importance of heredity in its etiology.

But beginning in the early 1900s,

The new psychological theories of Freud and his American followers challenged the hegemony of the congenital theory.... In his most radical thought, Freud posed heterosexuality as problematic in the same sense as homosexuality, by arguing that the suppression of any aspect of the libido required explanation.

(136-37)

6. See Lacan and Fuss, introduction. 


\section{Laura Green}

7. In the introduction to Palatable Poison, their recent anthology of critical responses to The Well of Loneliness, Doan and Prosser summarize the novel's reception throughout various periods (1-25). For an analysis of Stephen (and Hall) as tragic remnants of patriarchy, see, in that volume, Rule (77-88). The classic and influential reading of Stephen as a butch icon, "the mythic mannish lesbian," is, of course, Newton's. For a discussion of responses to The Well based on reader surveys, see O'Rourke chap. 5; and McNaron for the response of one group of students. The disparity between the emotional impact of Hall's novel and a reader's distaste for its aesthetic or ideological registers can still provoke unease. In The Apparitional Lesbian, Terry Castle calls The Well "that much-maligned yet still fiercely compelling fiction" (7) and characterizes Hall's style as "hieratic, overwrought, full of melodramatic, dismal pomp" (51); see also Castle in Doan and Prosser 394-402.

8. On technologies of sexuality, see Foucault, particularly 116-20. On the medicalization of lesbianism, see Chauncey; on the "construction of homosexuality" by sexology, see Weeks. For a summary of some assertions of the negative impact of sexology on women's same-sex interactions in particular, see Doan 199. See Doan and also Bland, however, for arguments that sexological pronouncements were open to a variety of constructions and that conservative applications "read [sexology] against itself" (Doan 211). See Prosser for a discussion of sexology as productive of transgender identity in The Well of Loneliness.

9. Epstein, who cites Laqueur's account of the historical development of these forms (29-30), argues that "the case report ... produces a context around groupings of symptoms and signs and findings and articulates these data into a narrative whose goal is to move toward explanation, therapy, and resolution" (75).

10. I am not the first reader to take Sandor as the most appropriate object for Stephen's identification: see, e.g., Prosser 158 and O'Rourke 3. But against such certainty, see Storr: "Hall does not actually tell us which chapter Stephen is reading. Even that section of chapter 4 which pertains particularly to homosexuality or 'inversion' is full of diverse possibilities" (12).

11. Storr discusses another case in the Psychopathia - that of Ilma S. - in similar terms:

Even as Krafft-Ebing records his power over Ilma, he records her resistance too. The intensity of his treatment of her is, at least in part, a response to the intensity of her refusal [to be "cured"].... Indeed all of the case histories in Psychopathia Sexualis reveal their subjects to be not 
just material, unruly or otherwise, for Krafft-Ebing's categories, but complex sites of negotiation.

Some of the case histories, however, reveal this complexity more clearly than others.

12. See Roof, particularly chap. 4, for another discussion of the "heteronarrative" domination of fictional conventions. The arguments of both Abraham and Roof have the effect of elevating historical (for Abraham) and modernist (for Abraham and Roof) narratives over those of the tradition of the domestic novel that Hall belongs to. For a defense of the romance plot in lesbian narrative, see Juhasz.

\section{Works cited}

Abel, Elizabeth. Virginia Woolf and the Fictions of Psychoanalysis. Chicago: U of Chicago P, 1989.

Abraham, Julie. Are Girls Necessary? Lesbian Writing and Modern Histories. New York: Routledge, 1996.

Allegra, Donna. "Between the Sheets: My Sex Life in Literature." Lesbian Erotics. Ed. Karla Jay. New York: New York UP, 1995. 71-81.

Baker, Michael. Our Three Selves: The Life of Radclyffe Hall. New York: Morrow, 1985.

Bland, Lucy. "Trial by Sexology?: Maud Allan, Salome, and the 'Cult of the Clitoris' Case." Bland and Doan 183-98.

Bland, Lucy, and Laura Doan, eds. Sexology in Culture: Labelling Bodies and Desires. Chicago: U of Chicago P, 1998.

Brittain,Vera. Radclyffe Hall: A Case of Obscenity? London: Femina, 1968.

Castle, Terry. The Apparitional Lesbian: Female Homosexuality and Modern Culture. New York: Columbia UP, 1993.

Chauncey, George Jr. "From Sexual Inversion to Homosexuality: Medicine and the Changing Conception of Female Deviance." Salmagundi no. 5859 (Fall 1982-Winter 1983): 114-46.

Cline, Sally. Radclyffe Hall: A Woman Called John. Woodstock, NY: Overlook, 1998.

Doan, Laura. “'Acts of Female Indecency': Sexology's Intervention in Legislating Lesbianism." Bland and Doan 199-213.

Doan, Laura, and Jay Prosser, eds. Palatable Poison: Critical Perspectives on The Well of Loneliness. New York: Columbia UP, 2001.

Epstein, Julia. Altered Conditions: Disease, Medicine, and Storytelling. New York: Routledge, 1995. 
Foster, Jeannette H. Sex Variant Women in Literature. 1956. New York: The Naiad Press, 1985.

Foucault, Michel. The History of Sexuality: An Introduction.Vol. 1.Trans. Robert Hurley. 1978. New York:Vintage, 1990.

Fuss, Diana. Identification Papers. New York: Routledge, 1995.

Halberstam, Judith. "A Writer of Misfits: John Radclyffe Hall and the Discourse of Inversion.” Female Masculinity. Durham: Duke UP, 1998. 75110.

Hall, Radclyffe. The Well of Loneliness. 1928. New York: Anchor, 1990.

Jay, Karla, and Joanne Glasgow, eds. Lesbian Texts and Contexts: Radical Revisions. New York: New York UP, 1990.

Juhasz, Suzanne. "Lesbian Romance Fiction and the Plotting of Desire: Narrative Theory, Lesbian Identity, and Reading Practice." Tulsa Studies in Women's Literature 17.1 (Spring 1998): 65-82.

Krafft-Ebing, R. von. Psychopathia Sexualis: A Medico-Forensic Study. Intro. Ernest van den Haag. Trans. Harry E. Wedeck. 1st unexpurgated English ed. New York: Putnam, 1965.

Lacan, Jacques. "The mirror stage as formative of the function of the I as revealed in psychoanalytic experience." Écrits: A Selection. Trans. Alan Sheridan. New York: Norton, 1977. 1-7.

Laqueur, Thomas W. "Bodies, Details, and the Humanitarian Narrative." The New Cultural History. Ed. Lynn Hunt. Berkeley: U of California P, 1989. 176-204.

MacPike, Loralee. "Is Mary Llewellyn an Invert? The Modernist Supertext of The Well of Loneliness." Unmanning Modernism: Gendered Re-Readings. Ed. Elizabeth Jane Harrison and Shirley Peterson. Knoxville: U of Tennessee P, 1997. 73-89.

Marcus, Jane. "Sapphistory:The Woolf and the Well." Lesbian Texts and Contexts: Radical Revisions. Ed. Karla Jay and Joanne Glasgow. New York: New York UP, 1990. 164-179. Rpt., in abridged form, from Jane Marcus, Virginia Woolf and the Languages of Patriarchy. Bloomington: Indiana UP, 1987.

McNaron, Toni. "A Journey into Otherness:Teaching The Well of Loneliness." Lesbian Studies: Present and Future. Ed Margaret Cruikshank. New York: Feminist, 1982. 88-92.

Newton, Esther. "The Mythic Mannish Lesbian: Radclyffe Hall and the New Woman.” Doan and Prosser 89-108.

O'Rourke, Rebecca. Reflecting on the Well of Loneliness. New York: Routledge, 1989. 
Parkes, Adam. "Lesbianism, History, and Censorship: The Well of Loneliness and the Suppressed Randiness of Virginia Woolf's Orlando." TwentiethCentury Literature 40.4 (Winter 1994): 434-460.

Prosser, Jay. Second Skins:The Body Narratives of Transsexuality. New York: Columbia UP, 1998.

Roof, Judith. Come as You Are: Sexuality and Narrative. New York: Columbia UP, 1996.

Rule, Jane. "Radclyffe Hall." Doan and Prosser 77-88.

Storr, Merl. "Transformations: Subjects, Categories and Cures in Krafft-Ebing's Sexology." Bland and Doan 11-26.

Weeks, Jeffrey. Sex, Politics, and Society: The Regulation of Sexuality Since 1800. New York: Longman, 1981.

Winning, Joanne. "Writing by the Light of The Well: Radclyffe Hall and the Lesbian Modernists.” Doan and Prosser 372-93.

Woolf,Virginia. The Diary of Virginia Woolf. Vol. 3, 1925-1930. Ed. Anne Olivier Bell with Andrew McNeillie. New York: Harcourt, 1980.

- The Letters of Virginia Woolf. Vol. 3, 1923-1928. Ed. Nigel Nicolson and Joanne Trautmann. New York: Harcourt, 1977. "Modern Fiction.” The Common Reader. First Series. New York: Harcourt, 1956. 150-58.

. A Room of One's Own. New York: Harcourt, 1929. 